УДК 330.142. 15

\title{
МІСЦЕ КОНТРОЛІНГУ В СИСТЕМІ ПІДВИЩЕННЯ ЕФЕКТИВНОСТІ МЕНЕДЖМЕНТУ ОРГАНІЗАЦІї
}

\author{
Герасименко В.М., ст. викладач (НА НГУ)
}

\begin{abstract}
В статті досліджується роль контролінгу в системі підвищення ефективності менеджменту організачії. Аналізуються особливості здійснення стратегічного контролінгу. Пропонується розгляд проблематики контролінгу з точки зору економічної теорії та розробки методичного інструментарію використання контролінгу в системі підвищення ефективності менеджменту організації. Розглядаються сучасні інструменти контролінгу, за рахунок застосування яких ведеться моніторинг функиіонування усіх відділів, служб та підрозділів підприємства.

Ключові слова: контролінг, функцї̈ контролінгу, інформаційна економіка, стратегічні рішення, управління, підприємство.
\end{abstract}

\section{МЕСТО КОНТРОЛЛИНГА В СИСТЕМЕ ПОВЫШЕНИЯ ЭФФЕКТИВНОСТИ МЕНЕДЖМЕНТА ОРГАНИЗАЦИИ}

Герасименко В.Н., ст. преподаватель (НА НГУ)

\begin{abstract}
В статье исследуется роль контроллинга в системе повышения эффективности менеджмента организаџии. Анализируются особенности осуществления стратегического контроллинга. Предлагается рассмотрение проблематики контроллинга с точки зрения экономической теории и разработки методического инструментария использования контроллинга в системе повышения эфрективности менеджмента организаџии. Рассматриваются современнье инструменты контроллинга, за счет применения которых ведется мониторинг функционирования всех отделов, служб и подразделений предприятия.
\end{abstract}

Ключевые слова: контроллинг, функции контроллинга, информационная экономика, стратегические рещения, управление, предприятие.

\section{CONTROLLING PLACE IN THE SYSTEM OF IMPROVING THE EFFICIENCY OF THE MANAGEMENT OF THE ORGANIZATION}

\author{
Gerasimenko V. M., senior lecturer \\ (National Academy of National guard of Ukraine)
}

During the period of the global economic crisis, the issue of effective management and ensuring the stable development of the enterprise is particularly acute. In Ukraine, the economy of which is closely integrated into world processes, the crisis has affected the activity of almost all enterprises. The main features of the environment in which modern enterprises are forced to work are: dynamic changes in the foreign economic environment, the stagnation of markets, the emergence of new technologies, reducing the life cycle of

(C) Герасименко В.M. $\quad$ Вісник економіки транспорту і промисловості № 61, 2018 
products. Today's economic situation is a test of the viability of enterprises in new, challenging conditions.

Strategic Controlling is an integral part of the management system for achieving the long-term goals of the enterprise, aimed at solving problems that are in line with the chosen strategy of the enterprise and which envisages the formulation of goals reflecting the desired state of the enterprise in the future, provided that the existing deviations are timely detected and eliminated in order to amend the company's strategy .

Strategic control tools are quite diverse, but most of them are used to identify future opportunities and risks for the enterprise. The interconnection of strategic control instruments is a kind of synthesis, the essence of which is the interpenetration and interchange of some elements of strategic control instruments.

By controlling the structures, the monitoring of the functioning of all departments, services, production and non-production divisions of the enterprise, which perform certain tasks in the economic-financial, production, marketing and other spheres, is monitored. Controlling structures should cover not only the activities of certain organizational units of the enterprise, but also monitoring the performance of certain functions by the responsible persons (by the centers of responsibility). Controlling the results should include the study of not only financial and economic performance of the enterprise, but also organizational and technical. This type of controlling involves analyzing the deviations of the above indicators of actual data from their normative values.

Keywords: controlling, controlling functions, information economy, strategic decisions, management, enterprise.

Постановка проблеми та іï зв'язки 3 науковими чи практичними завданнями. $\mathrm{У}$ період світової економічної кризи особливо гостро постає питання ефективного управління та забезпечення стабільного розвитку підприємства. В Україні, економіка якої тісно інтегрована в світові процеси, криза вплинула на діяльність практично всіх підприємств. Основними рисами середовища, в якому змушені працювати сучасні підприємства, є: динамічні зміни зовнішньоекономічного середовища, стагнація ринків, поява нових технологій, скорочення життєвого циклу продуктів. Сьогоднішня економічна ситуація $\epsilon$ тестом на життєздатність підприємств у нових складних умовах [1]. Водночас перевірку на життєздатність зазнають всі складові менеджменту підприємства - від стратегіï розвитку до ефективності організації бізнес-процесів. Виникнення кризової ситуації на багатьох українських підприємствах пов'язано з низьким рівнем менеджменту.
Аналіз останніх досліджень i публікацій та виділення невирішених частин загальної проблеми. В роботах $[2,3]$ наведено особливості здійснення стратегічного контролінгу. Сучасні інструменти контролінгу розглядаються в роботах [4, 5]. Розгляд проблематики контролінгу 3 точки зору економічної теорії пропонується в науковій праці [6]. Проте в літературних джерелах $\epsilon$ відсутнім системний розгляд контролінгу в сучасній практиці управління підприємством.

Отже, метою статті є дослідження ролі контролінгу в системі підвищення ефективності менеджменту організації.

Виклад основного матеріалу дослідження. Стратегічний контролінг це складова системи управління досягненням довгострокових цілей підприємства, спрямована на вирішення завдань, що відповідають обраній стратегії підприємства та яка передбачає формулювання цілей, що відображають бажаний стан підприємства в майбутньому за умови своєчасного

Вісник економіки транспорту і промисловості № 61, 2018 
виявлення та усунення наявних відхилень 3 метою внесення поправок до стратегії підприємства.

Головні функції контролінгу визначені в роботі [3]: адаптація підприємства до змін навколишнього середовища; координація функцій управління із довгостроковими цілями, їх реалізація та контроль у процесі стратегічного управління. Розглядаючи управління матеріальними ресурсами 3 позиції завдань управління, можемо визначити, що до їх складу відноситься розробка планів постачання матеріальних ресурсів; організація постачання ресурсів; відстеження виконання планів та ефективності використання матеріальних ресурсів; мотивація персоналу 3 управління матеріальними ресурсами. Завдання контролінгу полягають у наступному: інформаційно-аналітичне забезпечення; аналіз, планування, саморегулювання

підприємства; прийняття ефективних рішень; координаційно-консультативна система; технологія управління.

За наведеними системними зв'язками контролінг виступає інформаційним забезпеченням досягнення цілей та завдань підприємства. Він $€$ однією із ефективних систем керування підприємством, системою, економічна сутність якої полягає в процесі перетворення та інтеграції існуючих методів обліку, аналізу, планування i контролю в систему управління підприємством, орієнтовану на досягнення всіх завдань, що постають перед підприємством. $\mathrm{B}$ перспективі запровадження даного механізму дозволить знизити витрати підприємства за рахунок ефективного управління ресурсами, забезпечити конкурентоспроможність, зберегти та примножити власну долю на ринку. Даний механізм спрямований на ефективне стратегічне та оперативне планування, прогнозування та контроль, які дозволяють передбачити та вирішити проблеми в майбутньому [7].

Контролінг, як цілісна система (певний механізм), складається 3 двох важливих частин: стратегічного контролінгу та оперативного контролінгу.

Кожен з цих видів контролінгу має свої цілі, а також методи і інструменти для їх досягнення.

Стратегічний контролінг повинен забезпечити виживання підприємства, відстежувати намічені цілі розвитку i досягнення довгострокової стійкої переваги перед конкурентами. Відповідно, об'єктами контролю є такі показники, як цілі, стратегії, сильні і слабкі сторони фірми, шанси і ризики в бізнесі.

Зокрема, інструментами стратегічного управління, які використовує стратегічний контролінг, є: «власне виробництво - постачання 3 боку»; аналіз конкуренції; логістика; «портфельний аналіз»; аналіз потенціалу; «стратегічні розриви»; розробка «сценаріїв».

Оперативний контролінг орієнтований на короткострокові цілі i контролюе такі основні економічні показники фірми, як рентабельність, ліквідність і продуктивність [8].

Завдання, в основному, включають виробничий облік, оперативне планування i бюджетування, аналіз стандартів продуктивності і відношень, формування звітів, порівняння результатів 3 цілями, параметричний аналіз, формування звітів.

Основні методи і інструменти оперативного контролінгу досить сильно відрізняються від стратегічного. Найбільш відомими є наступні інструменти: «АВСаналіз»; аналіз об'єму замовлень; розрахунку сум покриття; оптимізація розмірів партії продукції; аналіз знижок та інші [6].

За допомогою стратегічного i оперативного фінансового контролінгу можна вирішити такі традиційні проблеми управління підприємством, як: низька платіжна дисципліна структурних

Вісник економіки транспорту і промисловості № 61, 2018 
підрозділів; неконтрольована дебіторська заборгованість; слабке управління витратами; невірне визначення прибутковості філій і видів бізнесу; сплата необгрунтовано високих податків в місцевий і загальнодержавний бюджети.

Виходячи 3 визначення системи контролінгу, його суттю $\epsilon$ інтеграція окремих елементів функцій управління (обліку, аналізу, контролю, планування).

Вибір методів контролінгу здійснюють одночасно у двох ракурсах:

- за видами предмета діяльності (контролінг процесу виробництва, контролінг фінансової діяльності тощо);

- за часом здійснення контролінгу (операційний, стратегічний).

Отже, незважаючи на один і той самий процес діяльності підприємства, для операційного і стратегічного видів контролінгу методи його дослідження докорінно відрізняються, а розглянута класифікація тісно пов'язана 3 теорією управління. Крім того, відзначимо, що поділ контролінгу за якимось одним критерієм не дає повної картини його структури. Для успішного впровадження цієї складної, але, безперечно, для багатьох підприємств дуже корисної інформаційної системи і ефективного використання іï можливостей необхідне бачення видів контролінгу через призму комплексної його класифікації [9].

Розглянемо детальніше характеристику загальних функцій контролінгу.

Інформаційна

функція проявляється у підготовці інформації для управління шляхом трансформації даних, що надходять у відділ контролінгу.

Управлінська функція (коментуюча або коментувальна) контролінгу полягає в тому, що не приймаючи безпосередньої участі в управлінні підприємством, він допомагає приймати ефективні управлінські рішення, тим самим покращуючи процес управління.

Функція планування передбачає перш за все, вибір концепції контролінгу і визначення його місця в системі управління, прийняття альтернативної стратегії відповідно до вибраної підприємством мети діяльності, тобто розроблення стратегічних бюджетів, встановлення підконтрольних показників, розроблення поточних планів постачання, виробництва, завоювання ринків збуту, розміщення капіталів, забезпеченість трудовими ресурсами в межах перспективних планів.

Обліково-контрольна функція оцінює ефективність роботи підприємства, контролює дотримання бюджетів для досягнення підприємством наміченої мети, спостерігає за виконанням завдань окремими структурними підрозділами, розробляє уніфіковані методи та критерії оцінки діяльності підприємства та окремих його підрозділів.

Аналітична функція контролінгу полягає в аналізі підконтрольних показників, встановленні відхилень від заданих параметрів, визначенні ступеня впливу кожного чинника на кінцеві результати роботи підприємства, в консультації керівників підприємства по виробленню заходів відносно недопущення знайдених недоліків у майбутньому.

Також контролінг на підприємстві може виконувати безліч спеціальних функцій, наприклад, збір та аналіз даних про кон'юнктуру ринку; порівняння даних роботи підприємства 3 досягнутими результатами конкурентів; обгрунтування доцільності злиття підприємства з іншими фірмами, або відкриття нових філіалів; проведення калькуляції окремих замовлень; розрахунки ефективності інвестиційних та інноваційних проектів тощо.

Служба контролінгу в процесі виконання своїх функцій вдається до багатьох методів загальнометодологічних i загальноекономічних (спостереження, порівняння, групування, аналіз, тенденційний аналіз, синтез, 
систематизація, прогнозування), так специфічних.

Практичне

застосування

фінансового контролінгу на підприємстві базується на використанні набору методів [10].

Інструменти

стратегічного контролінгу досить різноманітні, проте більшість 3 них використовують для виявлення майбутніх можливостей та ризиків для підприємства. Взаємозв'язок інструментарію стратегічного контролінгу $\epsilon$ свого роду синтезом, суть якого полягає у взаємопроникненні та взаємозаміні деяких елементів інструментів стратегічного контролінгу.

До головних специфічних інструментів стратегічного контролінгу належать такі:

- бенчмаркінг;

- вартісний аналіз;

- факторний аналіз відхилень;

- аналіз точки беззбитковості;

- портфельний аналіз;

- опитування (анкетування);

- СОФТ-аналіз (аналіз сильних та слабких місць);

- АВС-аналіз;

- Нуль-базис бюджетування [5].

Провівши детальний аналіз інструментів стратегічного контролінгу, вважаємо за доцільне виділити їх переваги та недоліки для подальшого впровадження у виробничо-господарську діяльність підприємства [2; 4]. На основі проведеного аналізу інструментарію стратегічного контролінгу, 3 виділенням переваг i недоліків окремо взятого інструменту на великих підприємствах доцільно використовувати: SWOT-аналіз, Balanced Scorecard, аналіз стратегічних розривів та аналіз потенціалів. Зокрема SWOT-аналіз відіграє важливе значення для здійснення стратегічного планування, оскільки це завжди ефективний, доступний, маловитратний засіб оцінки рівня управління на підприємстві.

За допомогою контролінгу структур ведеться моніторинг функціонування усіх відділів, служб, виробничих i невиробничих підрозділів підприємства, що виконують певні завдання в економічно-фінансовій, виробничій, маркетинговій та інших сферах. Контролінг структур повинен охоплювати не тільки діяльність тих або інших структурних підрозділів підприємства, але також моніторинг виконання певних функцій відповідальними особами (за центрами відповідальності). Контролінг результатів повинен охоплювати дослідження не лише фінансових i економічних показників діяльності підприємства, але й організаційно-технічних. Цей вид контролінгу передбачає аналіз відхилень вищезгаданих показників фактичних даних від їх нормативних значень.

Висновки. Таким чином, система стратегічного контролінгу $є$ новим поєднанням методів та принципів стратегічного управління, що дозволяє в іншій площині поглянути на проблему довгострокового існування підприємства в умовах ринку [11].

Запровадження на підприємстві системи стратегічного контролінгу допоможе запобігти виникненню кризових економічних ситуацій, ідентифікувати причини різних проблем та ефективно їх усунути. Також доцільно на великих підприємствах впроваджувати такі інструменти стратегічного контролінгу, як: SWOT-аналіз, Balanced Scorecard, аналіз стратегічних розривів та аналіз потенціалів - це дозволить вчасно ідентифікувати проблемні зони та використовувати наявний потенціал підприємства 3 мінімальними витратами ресурсів й максимально можливим позитивним ефектом в рамках обраної підприємством стратегії.

\section{ПЕРЕЛІК ВИКОРИСТАНИХ ДЖЕРЕЛ}

1.Каличева Н.С. Напрями забезпечення ефективного розвитку промислових підприємств в сучасних

Вісник економіки транспорту і промисловості № 61, 2018 
умовах/ Н.С. Каличева, С.С. Бохан// Науковий огляд. Науковий журнал. - Київ, ТОВ «Меганом», 2017. - Вип. 5 (37). С. 5 -15 .

2. Васильев П.Л. Механизм стратегического контроллинга в управлении конкурентоспособностью предприятия / П.Л. Васильев // Современные исследования социальных проблем. — 2014. — №4(36). - C. 32- 41 .

3. Гунченко М.В. Контролінг для менеджерів: навчальний посібник / М.В. Гунченко, I.А. Маркіна, О.М. Таран-Лала. К.: Центр учбової літератури, 2013. - 126 с.

$$
\text { 4. Мочона Л.Г. Сучасні }
$$
інструменти стратегічного контролінгу на підприємстві / Л.Г. Мочона // Бізнес Інформ. - 2013. - № 11. - C. 406416.
5. Соколовський

Адміністративний

навчальний посібник/
C.A. менеджмент:

C.

A. підприємства за рахунок маркетингової стратегії / В.М. Герасименко// Вісник економіки транспорту і промисловості: збірник науково-практичних статей. Харків: УкрДУЗТ. -2017. - №58. - С. 143152.

8. Науменко М.О. Управління розвитком кластерно-мережних структур/ М.О. Науменко// «Бізнес Інформ» ХНСУ, 2015. - Випуск № 3. - С. 269 - 275.

9. Науменко М.О. Розробка моделей стратегічного управління інтегрованими корпоративними структурами / M.O. Науменко// Science Rise. - 2017. - № 3 (32). - C. 25-28.

10. Науменко М.О. Удосконалення організаційної та фанкціональної структури логістичного забезпечення Збройних сил України /М.О. Науменко, Л.В. Морозова// «Бізнес Інформ». - ХНСУ, 2016. - Випуск № 3. - С. 269 - 275.

11. Каличева Н.С. Проблеми та
перспективи розвитку економіки України Соколовський, С. П. Павлов, М. В. Черкашина, М. О. Науменко. Х.: НАНГУ, 2017, - 216 c.

\section{6. Науменко М.О.Основи} економічної теорії: навчальний посібник/ M.O. Науменко, Б.А. Рудов, Л.В. Морозова. - Х.: АВВМВСУ, 2012, 340 с.

7. Герасименко В.М. Підвищення конкурентоспроможності продукції в сучасній світовій економічній системі / Н.Є. Каличева// Наука й економіка: Хмельницького економічного університету. - Хмельницький: ПВНЗ «Хмельницький економічний університет», 2015. - Вип. 4 (40). - С. 117 $-120$. науково-теоретичний журнал

\title{
УДК 658.6.001.63
}

\section{ТЕОРЕТИЧНІ АСПЕКТИ УПРАВЛІННЯ ПРОЕКТАМИ В ДІЯЛЬНОСТІ ТОРГОВЕЛЬНОГО ПІДПРИЕМСТВА}

\author{
Кірдіна О.Г., д.е.н., професор (УкрДУЗТ)
}

Пошук новітніх підходів до підвищення ефективності діяльності торговельного підприємства є одним з чи не найактуальніших питань сьогодення. Саме його вирішення можливе за рахунок концептуального впровадження практики управління проектами з метою розробки напрямків зменшення витрат, узгодженості стратегічного планування на різних рівнях, досягнення синергетичної ефективності при реалізації різних видів діяльності. Разом з тим, слід відзначити новизну 